\section{The relationship between physical activity and cholesterol levels in children and adolescents}

\section{Relação entre níveis de atividade física e valores de colesterolemia em crianças e adolescentes}

José Alberto Duarte 1

José Carlos Ribeiro 2

José Oliveira 3

Jorge Mota 4

1-4 CIAFEL. Faculty of Sport Sciences. University of Porto. Rua Dr. Plácido Costa, 91, 4200-450 Porto, Portugal.

\begin{abstract}
Objectives: to describe total cholesterol (TC) plasma levels according to age and sex; to determine the contribution of sex, age, body mass index and physical activity (PA) to TC variation; to determine the odds ratio for high total cholesterol (HTC) plasma levels of the subjects in the first PA quartile (lower $P A)$ in comparison to the fourth PA quartile.

Methods: the sample comprised 799 white children and adolescents, 353 males and 446 females. Body height and body weight were determined by standard anthropometric methods. Subject's capillary blood samples were taken from the earlobe after at least 12 hours fasting in order to obtain values of plasmatic TC. To calculate physical activity index (PAI) a PA questionnaire was used.

Results: the logistic regression of HTC for males and females showed that girls in the lower quartile of PAI, are 3.0 times ( $p<0.05$; 95\% CI: 1.3-6.8) as likely to belong at HTC group in relation to girls in the fourth PAI quartile. No significant influence was found in boys.

Conclusions: the results of the present study suggested that the higher TC values could be found even in early ages.
\end{abstract}

Key words Motor activity, Cholesterol, Risk factors, Cardiovascular diseases

\section{Resumo}

Objetivos: descrever os níveis plasmáticos de colesterol total (CT), de acordo com a idade e o sexo; determinar a contribuição do sexo, da idade, do índice de massa corporal e dos níveis de atividade física $(A F)$ habitual na variação do CT; determinar o odds ratio para o colesterol total elevado (CTE), nos sujeitos localizados no primeiro quartil de AF (níveis de AF mais baixos) comparativamente aqueles situados no quarto quartil.

Métodos: a amostra compreendeu 799 crianças e adolescentes caucasianos, 353 meninos e 446 meninas. A altura e o peso corporal foram determinados por métodos antropométricos usuais. Os valores plasmáticos de CT foram avaliados em amostras de sangue capilar recolhidas, em cada sujeito, no lóbulo auricular após, pelo menos, 12 horas de jejum. Os níveis de AF habitual foram avaliados por questionário.

Resultados: a regressão logística do CTE mostrou que as meninas situadas no quartil mais baixo de AF, comparativamente àquelas pertencentes ao quarto quartil, possuem um risco três vezes superior ( $p$ $<0,05$; 95\% CI: 1,3-6,8) de possuir níveis de CTE. Nenhuma influência significativa foi encontrada para os meninos.

Conclusões: os resultados sugerem que valores elevados de CT podem já ser encontrados nestas idades precoces.

Palavras-chave Atividade motora, Colesterol, Fatores de risco, Doenças cardiovasculares 


\section{Introduction}

Epidemiological studies have identified several traditional risk factors for cardiovascular diseases (CVD). Total cholesterol (TC) plasma levels has been shown to play an important role in CVD development. ${ }^{1,2}$ Some data suggested that TC tracks over years and therefore, high or low adult level seems to be related to TC values in childhood and adolescence. ${ }^{3,4}$ It was reported that about $40 \%$ of the subjects over the percentile 90 remained at the same level 20 years later ${ }^{5}$ which agreed with some population studies, such as data from Muscatine study. 6

Besides familiar history and diet, others factors seem to influence TC levels. ${ }^{1}$ Several authors have suggested that lifestyle physically active seems to have a beneficial effect on adults'lipid profile.7,8 However, similar to adults, studies in children and adolescents show a contradictory evidences in respect to lipid profiles changes induced by physical activity (PA).9,10 In fact, some studies suggest an inverse relation between $\mathrm{PA}$ and serum triglycerides (TG), 11,12 while other studies in paediatric populations failed to show significant relationship between TC and PA and concluded that TC is unaffected by PA. 13,14

Most of the studies designed to examine the association between lipid levels and PA are crosssectional.15 Armstrong and Simons-Morton 16 did a detailed analysis of all relevant studies until 1994 and concluded that the benefits from PA practice for lipid profile change were more evident in cross sectional studies. Moreover, the comparisons between the groups ("trained" vs "not trained", "actives" vs "not actives") provide the strongest evidences in relation to the possible effects of exercise in lipid profile. 17

In relation to longitudinal investigation, the literature suggests that habitual PA has little, if none influence on lipid profile of children. ${ }^{17}$ According to Armstrong and Simons-Morton, 16 the results of these studies are not clear, particularly due to the lack of precision in the experimental designs and the execution of studies. The inadequacy of PA programs might be due to weak dose-response relationship, namely related to the duration, intensity and type of exercise (run, bicycling, etc). 18

Although several studies failed to show significant associations between PA and TC in youth, the potential of PA to normalize lipid profile during childhood and adolescence cannot be ignored.17 Despite that PA might not have direct effects on lipid profile, it can provide indirectly, some influence for the change on lipid profile, through the change in life style. 16

The aim of the present study was determine in children: a) TC levels according to age and sex; b) the contribution of sex, age, body mass index (BMI) and PA to TC variation; c) the odds ratio for high total cholesterol (HTC), of the subjects in the first PA quartile (lower PA), in comparison to the fourth PA quartile.

\section{Methods}

This cross-sectional study was carried out as a part of a two-years observational longitudinal study looking at cardiovascular risk factors in children of both sexes aged 8-15 years from the region of Porto, Portugal. Furthermore the knowledge about the prevalence and incidence of these risk factors will allow the early detection of individuals with a high risk for CVD in adulthood, enabling the development of future early prevention and intervention programs.

\section{Participants}

This study was conducted at Porto area, Portugal, comprising 30 schools (17 primary schools and 13 high schools). More detailed information is described elsewhere. 19 The sample comprised 799 white children and adolescents from 8 to 15 years old, 353 males and 446 females. All children were apparently healthy and were free of any treatment. All measurements were completed between 9.00 and $11.00 \mathrm{am}$. The Portuguese Ministry for Science and Technology provided permission to conduct this study. Informed written consent was obtained from children's parents and individual school principals. Table 1 shows descriptive in body dimensions in males and females.

\section{Anthropometric measures}

Body height and body weight were determined by standard anthropometric methods. Height was measured to the nearest $\mathrm{mm}$ in bare or stocking feet with the child standing upright against an Holtain portable stadiometer. Weight was measured to the nearest $0.10 \mathrm{Kg}$, lightly dressed (underwear and teeshirt) using a Seca 708 portable digital beam scale. Intra-tester precision was reported before using technical error of measurement, which was $0.5 \%$ for weight and $0.8 \%$ for height, respectively. 20 Body mass index was calculated from the ratio weight /height $2\left(\mathrm{Kg} / \mathrm{m}^{2}\right)$. 
Number $(n)$ of subjects, mean $(\bar{X})$ and standard deviation (SD) of age, weight, height and body mass index (BMI) for males and females.

\begin{tabular}{|c|c|c|c|c|c|c|c|c|c|}
\hline & \multirow[b]{2}{*}{$\mathrm{n}$} & \multicolumn{2}{|c|}{$\begin{array}{c}\text { Age } \\
\text { (years) }\end{array}$} & \multicolumn{2}{|c|}{$\begin{array}{c}\text { Weight } \\
(\mathrm{Kg})\end{array}$} & \multicolumn{2}{|c|}{$\begin{array}{c}\text { Height } \\
(\mathrm{cm})\end{array}$} & \multicolumn{2}{|c|}{$\begin{array}{c}\text { BMI } \\
\left(\mathrm{Kg} / \mathrm{m}^{2}\right)\end{array}$} \\
\hline & & $\bar{x}$ & $(S D)$ & $\bar{x}$ & $(S D)$ & $\bar{x}$ & (SD) & $\bar{x}$ & (SD) \\
\hline Males & 353 & 10.8 & $(2.3)$ & 41.8 & (13.3) & 144.1 & (14.2) & 19.6 & (3.5) \\
\hline Females & 446 & 11.1 & $(2.4)$ & 41.5 & (11.8) & 143.8 & (12.7) & 19.7 & (3.5) \\
\hline
\end{tabular}

\section{Blood samples}

Subject's capillary blood samples were taken from the earlobe after at least 12 hours fasting in order to obtain values of plasmatic total cholesterol (TC). The blood samples were drawn in capillary tubes (33 $\mu 1$, Selzer) coated with lithium heparin and immediately assayed using Reflotron Analyser (Boehringer Mannheim, Indianapolis, IN). This instrument was, equally, used in previous investigations. 1,21,22 Statland 23 stated that the analysis method by dry chemistry, using the Reflotron Analyzer is a valid and reliable procedure for TC determination. The obtained TC values through this instrument have an error of $\pm 0.5 \% .23,24$ Additionally, this instrument allows us to obtained data in the field, since it is easy to transport. The Reflotron was daily calibrated with standard band.22 The measures obtained with this instrument are in accordance with the standard limits established by the Center for Disease Control, and the National Heart Lung and Blood Institute Standardization Program.21,25 The mean of the two measurements was considered for statistical analysis. In previous study, the mean intra-tester \% TEM was $3.1 \% .21$ Elevated levels of TC (HTC) were defined according to age and sex-adjusted $4^{\text {th }}$ quartile.

\section{Physical activity}

To calculate physical activity index (PAI) a PA questionnaire was used. This questionnaire was previously validated in a Portuguese sample by Mota et al. 26 In this questionnaire, the subjects were instructed to report only physical activities they did outside school in the last week and in which they are engaged for at least 15 minutes. Intensity categories were based on metabolic equivalents (MET's) that are multiples of resting metabolic rate. The final score was obtained in accordance to the methodology described by Sallis et al.,27 by multiplying the frequencies of each activity by its Met score and summing the product. The resulting score is in arbitrary units. Levels of physical activity were defined according the sex and age-adjusted PAI quartiles, where subjects belonging to the first quartile were defined as low level of physical activity (LPAI).

\section{Statistical analysis}

The data were analysed using the SPSS-PC 11.0 package for Windows. All the results given are expressed as means and standard deviation. TC and PAI quartiles, adjusted by sex and age, were calculated. Then, for TC the highest quartile was defined as the "high risk" quartile, while for PAI the lowest quartile was defined as the "high risk" quartile. Twoway ANOVA test was used to test the differences between gender and ages in the factors considered in the scope of this study. Pearson's correlation was used to find correlation coefficients between TC and the other variables. Multiple linear regression, as well as generalized linear model was used for studying the relation of age, sex, BMI and PAI with TC. In this regression, were considered the main effect as well as the interactions. Odds ratio and $95 \%$ confidence intervals were calculated for HTC (P75 of TC), using logistic regression for each PAI quartile, adjusting to age and sex. The significant level was set at $5 \%$.

\section{Results}

Mean and standard deviation for TC are present in Table 2. It can be observe that mean TC values decrease with age. The higher mean values in both sexes are present in early years. Thus, for females the higher mean TC value occurs at eight years old and for males at 12 years old. There is a decrease of $14 \%$ in means TC values in males and $7 \%$ in females. 
Mean TC values of our sample are lightly higher in females than males, except at 12 years old. In adolescence, females have higher values, probably because of their earlier maturation. 3,28

The results of the two-way ANOVA for TC are present in the baseboard of Table 2. As can be seen there was a statistical significant differences among ages sex and age. Furthermore an interaction between age and sex was observed. Therefore, TC changes according to age and that change is different for males and females.

\section{Table 2}

Number ( $n$ ) of subjects, mean ( $\bar{X})$ and standard deviation (SD) of total cholesterol (TC), by age and sex.

\begin{tabular}{|c|c|c|c|c|c|c|}
\hline \multirow{3}{*}{ Age } & \multicolumn{6}{|c|}{$\begin{array}{c}\mathrm{TC} \\
(\mathrm{mmol} / \mathrm{L})\end{array}$} \\
\hline & \multicolumn{3}{|c|}{ Males } & \multicolumn{3}{|c|}{ Females } \\
\hline & $n$ & $\bar{x}$ & SD & $\mathrm{n}$ & $\bar{x}$ & SD \\
\hline 8 & 52 & 4.3 & $(0.6)$ & 59 & 4.5 & $(0.7)$ \\
\hline 9 & 104 & 4.4 & $(0.8)$ & 120 & 4.4 & (0.6) \\
\hline 10 & 50 & 4.4 & $(0.5)$ & 65 & 4.4 & (0.7) \\
\hline 11 & 6 & 4.2 & $(0.8)$ & 6 & 4.3 & (0.5) \\
\hline 12 & 20 & 4.7 & $(0.8)$ & 29 & 4.2 & (0.7) \\
\hline 13 & 64 & 4.2 & $(0.7)$ & 77 & 4.3 & (0.7) \\
\hline 14 & 30 & 3.8 & $(0.6)$ & 52 & 4.3 & $(0.7)$ \\
\hline 15 & 29 & 3.7 & $(0.4)$ & 41 & 4.2 & (0.7) \\
\hline
\end{tabular}

Comparisons by two-way ANOVA: age, $\mathrm{F}=6.3(p<0.001)$; sex, $\mathrm{F}=3.1(p=0.080)$ age $\mathrm{x}$ sex, $\mathrm{F}=3.2(p<0.005)$

Tables 3 and 4 present a multiple linear regression model and interactions between TC as dependent variable and age, sex, BMI, PAI as independent ones. Age, sex and their interactions explain 3.9\% $\left(\mathrm{R}^{2}=0.039\right)$ of $\mathrm{TC}$ variation.
The logistic regression of HTC for males (Table 5) and females (Table 6) showed that girls in the lower quartile of PAI are 3.0 times ( $p<0.05$; 95\%CI: 1.3-6.8) as likely to belong at HTC group in relation to girls in the fourth PAI quartile. No significant influence was found in boys.

Table 3

Pearson correlation coefficients between total cholesterol (TC) for age, weight, height, body mass index (BMI and physical activity index (PAI), for males and females.

\begin{tabular}{llllll}
\hline & Age & Weight & Height & BMI \\
\hline Males & $-0.262 * *$ & $-0.257 * *$ & $-0.295^{* *}$ & -0.103 \\
Females & $-0.134 * *$ & $-0.127 * *$ & $-0.162 * *$ & -0.032 & -0.049 \\
\hline
\end{tabular}

** $\mathrm{p}<0.01$ 
Multiple linear regression for total cholesterol (TC).

\begin{tabular}{lcc}
\hline & & CT \\
Variables & $B$ & $\mathrm{p}$ \\
\hline Constant & 4.760 & $<0.001$ \\
Age & -0.038 & $<0.001$ \\
Sex & 0.333 & 0,070 \\
Age*Sex & -0.040 & $<0.050$ \\
\hline
\end{tabular}

$\mathrm{R}^{2}=0.039$

Table 5

Odds ratio and $95 \%$ confidence intervals $(95 \% \mathrm{CI})$ for high total cholesterol (HTC) in relation to physical activity index (PAI), for males.

\begin{tabular}{|c|c|c|c|c|c|c|}
\hline \multirow{2}{*}{ PAI } & \multicolumn{6}{|c|}{ HTC } \\
\hline & $\mathrm{n}$ & $\begin{array}{c}<\text { P75 } \\
(\%)\end{array}$ & $\begin{array}{c}\geq \text { P75 } \\
(\%)\end{array}$ & Odds ratio & $95 \% \mathrm{Cl}$ & $p$ \\
\hline 1st quartile & 59 & (76.3) & $(23.7)$ & 1.0 & $0.4-2.4$ & 0,950 \\
\hline 2nd/3rd quartile & 113 & (71.7) & $(28.3)$ & 1.3 & $0.6-2.7$ & 0,480 \\
\hline 4th quartile & 56 & $(76.8)$ & $(23.2)$ & 1.0 & - & - \\
\hline
\end{tabular}

Table 6

Odds ratio and $95 \%$ confidence intervals $(95 \% \mathrm{Cl})$ for high total cholesterol (HTC) in relation to physical activity index (PAI), for females.

\begin{tabular}{|c|c|c|c|c|c|c|}
\hline \multirow{2}{*}{ PAI } & \multicolumn{6}{|c|}{ HTC } \\
\hline & $\mathrm{n}$ & $\begin{array}{c}<\text { P75 } \\
(\%)\end{array}$ & $\begin{array}{c}\geq \text { P75 } \\
(\%)\end{array}$ & Odds ratio & $95 \% \mathrm{Cl}$ & $\mathrm{p}$ \\
\hline 1st quartile & 83 & $(65.1)$ & (34.9) & 3.0 & $1.3-6.8$ & $<0.050$ \\
\hline 2nd/3rd quartile & 162 & $(75.9)$ & $(24.1)$ & 1.8 & $0.8-3.8$ & 0,140 \\
\hline 4th quartile & 66 & $(84.8)$ & $(15.2)$ & 1.0 & - & - \\
\hline
\end{tabular}

\section{Discussion}

Cross-sectional studies are useful to describe the risk factor profile in a population, providing information of the relationship between different variables. It is important to elucidate when and how these relationships are established and how the risk factors behave.
The results of the present study showed that regardless gender plasma TC concentrations decreased as the children grew-up, with a steeper TC decline in boys (14\%) rather than in girls $(7 \%)$. Our data also suggested that the highest mean values are presented in early ages, which agrees with several other outcomes.22,29,30,31 Labarthe et al.30 reported 
that the highest TC values were observed at nine and 10 years, being 4.32 and $4.34 \mathrm{mmol} / \mathrm{L}$ for females and males, respectively. In the study of Resnicow et al.,32 integrated in "Know Your Body School Health Program", the highest mean TC values were found at eight to 10 years for females and 10 years for males. In the study of Fukushige et al., 33 the highest TC value was reached at nine years of age in both sexes. At this age and for both sexes, Schulpis and Karikas $^{31}$ reported the highest TC values (4.50 $\mathrm{mmol} / \mathrm{L}$ for males and $4.45 \mathrm{mmol} / \mathrm{L}$ for females).

Related to gender we found that mean TC values in girls tend to be higher than males, which was also shown 34,35 and is likely linked to girls' earlier maturation. 3,28 Furthermore, mean TC values obtained in our study are slightly higher in all ages and in both sexes. 30,31 These observations suggest that the use of values obtained in others populations does not be a more correct procedure to define cut off points. In fact, the distinct methodologies used in different studies as well as the cultural and biological factors and life style characteristics, might explain the differences found and limit the criterion values obtained in a population and use in another one.36,37

Wynder et al.,38 studied the influence of geographic factors in TC values on 5331 subjects aged 13 years-old in 15 countries. They follow the cut point valued defined by Abell et al.,39 to define hypercholesterolemia (180 mg/dL - $4.65 \mathrm{mmol} / \mathrm{L})$. The authors concluded that hypercolesterolemia is already presented in children in different countries of Europe. Since the prevalence of that risk factor for CVD vary in children of different countries, the authors assume that those variation are likely due to the lifestyle differences and thus they suggested that do not use the criterion values of others countries. Based on this suggestion its seems that our approach using the definition of 'risk' quartiles based on arbitrary cut points, related to the observed distributions rather than on objective fixed cut off point, is an interesting approach because the 'risk groups' are the target population for prevention of disease.

The multiple linear regression analysis showed that only age, sex and their interaction were significant and explains $3.9 \%$ of TC variation. This agree with Suter and Hawes, 40 report shown that the explained variance in TC their was low $(12.1 \%$ and $20.2 \%$ ). Therefore, a considerable TC variation is still to be explained. Bergstrom et al. ${ }^{41}$ report that, in adolescence, lipids are primary related to age and sex. However others variables, like familiar history of CVD, infant feeding, physical growth and many others factors that were not controlled in our study might influence TC variation. A multivariate analysis by Wong et al.,22 in 1081 children and adolescents showed that the expended time watching television was the most important predictor of TC values equal or above $200 \mathrm{mg} / \mathrm{dL}(5.2 \mathrm{mmol} / \mathrm{L})$. Other studies, such as carried out by Thorland and Gilliam ${ }^{42}$ didn't find significant differences between TC and HDL-C levels of high and low active preadolescents males. Although our results from the multiple linear regression analysis were not significant regarding PA influence on TC level, the logistical regression analysis suggested that in girls but not in boys, PA have an influence in TC values. In fact, girls in the lower quartile of PAI, are 3.0 times ( $p$ $<0.05$; 95\%CI: 1.3-6.8) as likely to belong at HTC group in relation to girls in the fourth PAI quartile. These results reinforce the hypothesis that PA has a potential benefit in lowering the TC values, at least in girls. Therefore still should be as main focus of health-related PA concerns to encourage an active lifestyle in youngsters.

Some limitations should be recognized. Our study was a cross-sectional designed and therefore causality between TC and PA should be considered with caution. Additionally confounding influences of other CVD risk factors as growth and maturation were beyond of the scope of this study and therefore longitudinal analysis looking for the relationship of maturation on TC would be useful.

\section{Conclusions}

The results of the present study suggested that the higher TC values were found in early ages and then decrease with age, in both sexes with boys showing a steeper decrease. Rather, girls showed higher TC values in all ages, except at 12 years old.

The results obtained in this study reinforce the controversy of the relation between PA and HTC in children and adolescents. Age, sex and their interactions explain $3.9 \%$ of TC variation. However, the results obtained in logistical regression analysis in girls suggested that those belonging to the lower PAI quartile are 3.0 times as likely to belong at HTC group. 


\section{Acknowledgement}

This study was supported by grants: Práxis XXI PSAU/126/96 and Fundação Calouste Gulbenkian: Proc-48988.

\section{References}

1. Hopper C, Gruber M, Munoz K, MacConnie S, Pfingston Y, Nguyen K. Relationship of blood cholesterol to body composition, physical fitness, and dietary intake measures in third grade children and their parents. Res Q Exerc Sport 2001; 72: 182-8

2. Stamler J, Wentworth D, Neaton JD. Is relationship between serum cholesterol and risk of premature death from coronary heart disease continuous and graded? Findings in 356222 primary screenees of the multiple Risk Factors Intervention Trial (MRFIT). JAMA 1986; 256: 2823-28.

3. World Health Organization. Prevention in childhood and youth of adult cardiovascular diseases: time for action. World Health Organ Tech Rep Ser 1990; 792: 1-105.

4. Twisk J, Kemper HCG, Snel J. Tracking of cardiovascular risk factors in relation to lifestyle. In: Kemper HCG, editor. The Amsterdam growth study: a longitudinal analysis of health, fitness and lifestyle. Champaign: Human Kinetics; 1995.

5. Barker DJP, Osmond C, Golding J. Growth in utero, blood pressure in childhood and adulta life, and mortality from cardiovascular disease. BMJ 1989; 298: 564-7.

6. Lauer RM, Lee J, Clarke WR. Factors affecting the relationship between childhood and adult cholesterol levels: the muscatine study. Pediatrics 1988; 82: 309-18.

7 Williams P, Krauss R, Vranizan K, Wood P. Changes in lipoprotein subfractions during diet-induced and exercise-induced weight loss in moderately overweight men. Circulation 1990; 81: 1293-304.

8. Wood P, Stefanick M, Dreon D, Frey- Hewitt B, Garay S, Williams P, Superko H, Fortmann S, Albers J, Vranizan $\mathrm{K}$. Changes in plasma lipids and lipoproteins in overweight men during weight loss through dieting as compared with exercise. N Engl J Med 1988; 319: 1173-9.

9. Andersen L, Haraldsdottir J. Tracking of cardiovascular disease risk factors including maximal oxygen uptake and physical activity from late teenage to adulthood. An 8 year follow-up study. J Intern Med 1993; 234: 309-15

10. Armstrong N, Welsman J. Young people and physical activity. Oxford (NY): Oxford Medical Publications; 1997.

11. Perusse L, Despres J, Tremblay A, Leblanc C, Talbot J, Allard C, Bouchard C. Genetic and environmental determinants of serum lipids and lipoproteins in French Canadian families. Arteriosclerosis 1989; 9: 308-18.

12. Tell G, Vellar O. Physical fitness, physical activity, and cardiovascular disease risk factors in adolescents: the Oslo Youth Study. Prev Med 1988; 17: 12- 24.

13. Armstrong N, Williams J, Balding J. Cardiopulmonary fit- ness, physical activity patterns and selected coronary risk factor variables in 11 to 16 year olds. Pediatr Exerc Sci 1991; 3: 219-28.

14. Al-Hazzaa HM, Sulaiman MA, Al-Matar AJ. Cardiorespiratory fitness, physical activity patterns and coronary risk factors in preadolescent boys. Int J Sports Med 1994; 15: 267-72.

15. Twisk JWR. Physical activity, physical fitness, and cardiovascular health. In: Armstrong N, van Mechelen W, editors. Paediatric exercise science and medicine. Oxford (NY): Oxford University Press; 2000. p. 253-63.

16. Armstrong N, Simons- Morton B. Physical activity and blood lipids in adolescents. Pediatr Exerc Sci 1994; 6: 381-405.

17. Tolfrey K, Jones A, Campbell I. The effect of aerobic exercise training on the lipid-lipoprotein profile of children and adolescents. Sports Med 2000; 29: 99-112.

18. Haskell W, Wolffe JB. Memorial lecture. Health consequences of physical activity: understanding and challenges regarding dose-response. Med Sci Sports Exerc 1994; 26: 649-60.

19. American College of Sports Medicine Position Stand. The recommended quantity and quality of exercise for developing and maintaining cardiorespiratory and muscular fitness a.f.i.h.a. Med Sci Sports Exerc 1998; 30: 975-91.

20. Guerra S, Santos P, Ribeiro J, Duarte J, Mota J, Sallis JF. Assessment of children and adolescents physical activity level. Eur J Physic Educ Rev 2003; 9: 75-86.

21. Garcia R, Moodie D. Routine cholesterol surveillance in childhood. Pediatrics 1989; 84: 751-5.

22. Wong N, Heit T, Qaqundah P, Davidson D, Basin S, Gold K. Television viewing and pediatric hypercholesterolemia. Paediatrics 1992; 90: 75-9.

23. Statland B. A review of the analytic performance of the Reflotron System for cholesterol testing. Clin Ther 1990; 12: 281-6.

24. Selmer R, Foss O, Lund-Larsen P. Reliability of the Reflotron in the determination of cholesterol. Scand J Clin Lab Invest 1990; 50: 261-71.

25. Pearson J, Dusenbury L, Bakes-Martin R, Loverde M, Johnson J, Byyny R. Evaluation of a simple method for measuring blood cholesterol levels using non-laboratory observers. Am J Med 1988; 85: 369-74.

26. Mota J, Santos P, Guerra S, Ribeiro JC, Duarte JA, Sallis JF. Validation of physical activity self-report questionnaire in a portuguese pediatric population. Ped Exerc Sci 2002; 14: 269-76. 
27. Sallis JF, Condon SA, Goggin JJ, Roby B, Kolody B, Alcaraz JE. The development of self-administered physica activity surveys for 4 th grade students. Res Q Exerc Sport 1993; 64: 25-31

28. Viikari J, Ronnemaa T, Seppanen A, Marniemi J, Porkka K, Rasanen L, Uhari M, Salo M, Kaprio E, Nuutinen E. Serum lipids and lipoproteins in children, adolescents and young adults in 1980-1986. Ann Med 1991; 23: 53-9.

29. Christensen B, Glueck C, Kwiterovich P, Degroot I, Chase G, Heiss G, Mowery R, Tamir I, Rifkind B. Plasma cholesterol and triglyceride distributions in 13, 665 children and adolescents: the prevalence study of the lipid research clinics program. Pediatr Res 1980; 14: 194-202.

30. Labarthe D, Nichaman M, Harrist R, Grunbaum J, Dai S. Development of cardiovascular risk factors from ages 8 to 18 in Project HeartBeat! Study design and patterns of change in plasma total cholesterol concentration. Circulation 1997; 95: 2636-42.

31. Schulpis K, Karikas G. Serum cholesterol and triglyceride distribution in 7767 school-aged Greek children. Pediatrics 1998; 101: 861-4.

32. Resnicow K, Morley-Kotchen J, Wynder E. Plasma cholesterol levels of 6585 children in the United States: results of the know your body screening in five states. Pediatrics 1989; 84: 969-76.

33. Fukushige J, Igarashi H, Ueda K, Akazawa K, Nose Y. Serum cholesterol levels in school- aged Japanese chil dren: the Hisayama study. Acta Paediatr 1996; 38: 22-7.

34. Lipid Research Clinics Population Studies Data Book prevalence study. Washington (DC): US Department of Health and Human Services; 1980. p. 80-1527.
35. Frerichs R, Srinivasan S, Webber L, Berenson G. Serum cholesterol and triglyceride levels in 3446 children from a biracial community: the Bogalusa Heart Study. Circulation 1976; 54: 302-9.

36. Kannel W, Castelli W, Gordon T, McNamara P. Serum cholesterol, lipoproteins, and the risk of coronary heart disease. The Framingham study. Ann Intern Med 1971; 74: $1-12$.

37. Bell RD, Macek M, Rutenfranz J. Health indicators and risk factors of cardiovascular diseases during childhood and adolescence. In: Rutenfranz J, Mocelin R, Klimt F, editors. Children and exercise XII. Champaign: Human Kinetics; 1986. p. 19-27.

38. Wynder E, Williams C, Laakso K, Levenstein M. Screening for risk factors for chronic disease in children from fifteen countries. Prev Med 1981; 10: 121-32.

39. Abell L, Levy B, Brodie B, Kendall F. A simplified method or estimation of total cholesterol in serum and demonstration of its specificity. J Biol Chem 1952; 195: 35766.

40. Suter E, Hawes M. Relationship of physical activity, body fat, diet, and blood lipid profiles in youths 10- $15 \mathrm{yr}$. Med Sci Sports Exerc 1993; 25: 748-54.

41. Bergstrom E, Hernell O, Persson L, Vessby B. Serum lipid values in adolescents are related to family history, infant feeding, and physical growth. Atherosclerosis 1995; 117: $1-13$.

42. Thorland WG, Gilliam TB. Comparison of serum lipids between habitually high and low active pre-adolescent males. Med Sci Sports Exerc 1981; 13: 316-21.

Recebido em 29 de março de 2004

Versão final apresentada em 4 de abril de 2004

Aprovado em 6 de maio de 2004 